\title{
DEBAT CAPRES CAWAPRES DALAM PERSPEKTIF SYARIAT ISLAM ( TINJAUAN ANALISIS SEMIOTIKA DEBAT CAPRES CAWAPRES PEMILU 2019)
}

\author{
A.NUR AISYAH RUSNALI \\ Program Studi Komunikasi dan Penyiaran Islam \\ Institut Agama Islam Negeri Bone \\ rusnaliaisyah@gmail.com
}

\begin{abstract}
:
The purpose of this study is to find out how the debate of the Capres and Cawapres 2019, and to explore the view of Islamic Shari'a on the debates of the Capres and Cawapres 2019, is reviewed from a semiotic communication study. The research method used is qualitative with a semiotic communication approach. Semiotics is about the meaning of signs, markers, and signs. The debate in human life is a humane thing to happen. Because all mankind can't have the same thoughts. Depending on humans, the debate itself is. As is the case in determining the president's choice. Law in the ability of debate or discussion, Islam has arranged it in such away. , Islamic law on the debate is not to do debate only for pleasure, it occurs in the debate program of 2019 candidate. The debate Program is carried out not for pleasure alone, but accompanied by a good purpose, namely to make the community more familiar with the character of each candidate President and vice president, so that they easily determine the choice.
\end{abstract}

Keywords: the candidate debate,Islamic Sharia, Semiotics.

\begin{abstract}
Abstrak:
Tujuan dari penelitian ini adalah untuk mengetahui bagaimana pelaksanaan Capres dan Cawapres 2019, dan untuk mengeksplorasi pandangan Syariah Islam tentang debat Capres dan Cawapres 2019, ditinjau dari studi semiotika komunikasi. Metode penelitian yang digunakan adalah kualitatif dengan pendekatan semiotika. Semiotika adalah tentang makna tanda, penanda, dan tanda. Perdebatan dalam kehidupan manusia adalah hal yang manusiawi terjadi. Karena semua umat manusia tidak dapat memiliki pikiran yang sama. Tergantung bagaimana manusia, memaknai perdebatan itu sendiri. Seperti halnya dalam menentukan pilihan presiden. Hukum dalam debat atau diskusi, Islam telah mengaturnya sedemikian rupa., Hukum Islam tentang perdebatan bukan hanya untuk kesenangan, itu terjadi dalam program debat 2019 kandidat. Program debat dilakukan bukan untuk kesenangan semata, tetapi disertai dengan tujuan yang baik, yaitu untuk membuat masyarakat lebih mengenal karakter masing-masing calon Presiden dan wakil presiden, sehingga mereka dengan mudah menentukan pilihan.
\end{abstract}

Kata kunci: debat capres cawapres, syariat islam,semiotika. 


\section{PENDAHULUAN}

Indonesia merupakan Negara demokrasi yang berlandaskan Pancasila dan UUd 1945. Segala sesuatu yang berkaitan dengan pemerintahan telah diatur dalam Undang- Undang. Indonesia sendiri telah melewati tiga fase pemerintahan sejak memproklamirkan kemerdekaan pada tanggal 17 Agustus 1945. Ketiga fase tersebut yakni, Orde Lama. Orde Baru, dan Reformasi yang masih berlaku sampai saat ini. Berbeda denga kedua fase sebelumnya, dimana semua keputusan berpusat pada pemerintah. Pada masa reformasi ini, seluruh keputusan berada di tangan rakyat atau lebih dikenal dengan istilah demokrasi. Dimana semua rakyat Indonesia berhak untuk menyatakan pendapat dan pikiran mereka, termasuk dalam menentukan pemimpin bangsa.

Pemilihan umum (pemilu) di Indonesia pada awalnya ditujukan untuk memilih anggota lembaga perwakilan, yaitu DPR, DPRD Provinsi, dan DPRD Kabupaten/Kota. Setelah amendemen keempat UUD 1945 pada 2002, pemilihan presiden dan wakil presiden (pilpres), yang semula dilakukan oleh MPR, disepakati untuk dilakukan langsung oleh rakyat dan dari rakyat sehingga pilpres pun dimasukkan ke dalam rangkaian pemilu. Pilpres sebagai bagian dari pemilu diadakan pertama kali pada Pemilu 2004. Pada 2007, berdasarkan UndangUndang Nomor 22 Tahun 2007, pemilihan kepala daerah dan wakil kepala daerah (pilkada) juga dimasukkan sebagai bagian dari rezim pemilu.

Pemilu secara langsung di Indonesia pertama kali dilaksanakan padat tahun 2004. Pada saat itu, yang keluar sebagai pemenang adalah Susilo Bambang Yudhoyono dan berhasil pula memenangkan suara pada periode selanjutnya di tahun 2009. Pada tahun 2014, Jokowidodo berpasangan dengan Jusuf Kalla berhasil memenangkan pemilu dan mengikuti jejak SBY menang selama dua periode. Namun pada periode kedua di tahun 2019, Jokowi berpasangan dengan K.H.Ma'ruf Amin.

Selama pemilu dilaksanakan secara langsung, tentunya hal tersebut tidak lepas dari aktifitas kampanye yang maksimal oleh masing- masing kandidat. Mulai dari pemasangan baliho di setiap daerah, iklan di televisi, media sosial, surat kabar, sampai pada program debat Capres Cawapres yang diadakan oleh 
KPU dan disiarkan langsung di televisi- televisi swasta. Program debat tersebut merupakan acara yang paling banyak dinantikan oleh seluruh masyarakat Indonesia, baik di dalam maupun di luar negeri. Bagi masyarakat yang bermukim di luar negeri, dapat menyaksikan tayangan tersebut secara streaming melalui chanel Youtube.

Pelaksanaan debat Capres Cawapres yang dilakukan oleh KPU tentunya memiliki alasan tersendiri. Menurut Dennis McQuail dalam Henry Subiakto, suatu kampanye kemungkinan berhasil jika ada kondisi tertentu yang mendukung pada situasi audience, pesan, dan sumber. Untuk audiensi, pertama kampanye harus dapat menjangkau khalayak yang luas. Kedua, audiensi yang dijangkau itu harus sesuai dengan sasaran kampanye. Ketiga, sifat khalayak yang dituju tidak mempunyai sikap antipasti terhadap materi kampanye. Keempat, kampanye akan berhasil jika didukung oleh struktur komunikasi int sumber, perlu adanya kondisi interpersonal yang sesuai dengan yang diharapkan. Kelima, audiensi benar- benar dapat memahami isi kampanye secara benar. Pada sumber, usahakan adanya monopoli, yakni seluruh saluran komunikasi digunakan untuk menyampaikan pesan kampanye yang sama. Sedangkan kondisi pada media yang digunakan, media harus akrab dengan khalayak dan disesuaikan dengan sasaran yang dituju. ${ }^{1}$

Berangkat dari pendapat Mc,Quail di atas, maka dapat dikatakan bahwa program debat tersebut dijadikan sebagai ajang kampanye yang efektif bagi masing- masing paslon Capres dan Cawapres. Mereka tidak lagi harus turun langsung ke daerah- daerah pelosok yang sulit dijangkau untuk melakukan kampanye. Cukup tampil di televisi dengan memberikan performance terbaik untuk menarik suara rakyat.

Dalam program acara Debat Capres Cawapres terdapat tanda atau signal dalam konteks komunikasi yang melibatkan berbagai elemen komunikasi, baik dari panggung (stage), latar belakang panggung (stage background), gerak-gerik dari masing- masing paslon pasti mempunyai makna yang bisa diinterpretasikan berbeda-beda oleh pemirsa/penonton.

${ }^{1}$ Henry subiakto, Rhamah Ida, Komunikasi Politik, media dan Demokrasi,edisi kedua (Cet. II; Jakarta: Prenadamedia Group, 2012), h. 107. 
Tanda dalam pandangan Charles Sanders Pierce diketahui berada dalam proses penciptaan rangkaian interpretasi tanpa akhir. Didalam semiotika komunikasi, tanda atau signal ditempatkan didalam rantai komunikasi, sehingga tanda itu mempunyai peran yang penting dalam komunikasi. ${ }^{2}$ Namun hal lain yang menarik perhatian adalah, Negara Indonesia dengan penduduk yang mayoritas beragama Islam memberikan reaksi yang berbeda- beda terhadap program debat tersebut. Ada yang memberikan respon positif, namun tidak banyak pula yang memberikan tanggapan negatif terhadap acara tersebut. Berangkat dari fenomena tersebut, bagaimanakah sesungguhnya syariat Islam memandang program acara debat tersebut? Apakah telah sesuai dengan syariat Islam, ataukah malah melenceng dari syariat? Oleh karena itu, peneliti tertarik untuk melakukan kajian semiotika komunikasi terhadap program acara debat Capres dan Cawapres 2019.

\section{TINJAUAN PUSTAKA}

Penelitian mengenai semiotika komunikasi baik film, iklan, programprogram televisi telah banyak dikaji oleh peneliti- peneliti dalam kajian ilmu komunikasi. Namun penelitian yang akan dilakukan kali ini akan mengambil objek yang berbeda yakni program debat Capres dan Cawapres 2019 menurut pandangan Syariat Islam.

\section{Media Massa Televisi}

Media massa televisi mempunyai pengaruh yang besar bagi kehidupan masyarakat modern, banyak aspek dalam kehidupan manusia dipengaruhi oleh tayangan televisi. Kehadiran program debat Capres dan Cawapres di layar televisi, memberikan warna baru bagi dunia pertelivisian. Program debat Capres Cawapres merupakan salah satu bentuk komunikasi massa melalui perantara media, yakni

\footnotetext{
${ }^{2}$ Piliang, Yasraf Amir, Semiotika dan Hipersemiotika: Gaya, Kode dan Matinya Makna.
} Ed. 4. (Cet. I; Bandung: Matahari, 2012). h. 340. 
televisi. Proses politik, tidak akan pernah lepas dari peran media massa dalam menyebar luaskan informasi.

Pada tahun 1976, Ford dan Jimmy Carter bersaing menjadi Presiden Amerika Serikat. Semalam sebelum the great debate- perdebatan calon Presiden di televisi, polling menunjukkan Ford lebih unggul 11 persen dari Carter. Di perdebatan, Carter tampil lebih memikat. Walhasil setelah perdebatan, polling menunjukkan Ford tertinggal 45 persen di belakang Carter. Ini berarti, hanya dalam waktu sehari semalam televisi telah merugikan Ford 56 persen point. Sejak itu, hampir semua calon Presiden Amerika Serikat semakin terlibat menggunakan media massa, terutama televisi. Ada keyakinan bahwa, popular tidaknya calon Presiden banyak dipengaruhi penampilannya di televisi. ${ }^{3}$ hal tersebut sepertinya telah menular ke Negara- Negara lain termasuk Indonesia.

Kekutan media khususnya televisi untuk memberikan pengaruh memang sudah tidak diragukan lagi. Telah banyak peneliti- peneliti yang mengkaji tentang pengaruh televisi bagi masyarakat. Baiak itu anak- anak, remaja, dan dewasa. Menurut Hafied Cangara dalam bukunya " komunikasi politik", media memang menjadikan para politisi sebagai pembuat berita (news maker). Melalui media, mereka mengenal wajah dan latar belakang calon. Bahkan juga anak- anak yang belum punya hak pilih banyak mengetahui tentang calon yang diekspose oleh media. ${ }^{4}$

\section{Analisis Semiotika}

Semiotika telah banyak digunakan oleh berbagai disiplin ilmu dalam berbagai penelitian. Tak terkecuali dalam bidang komunikasi. Adapun pengertian semiotika menurut Kamus Besar Bahasa Indonesia adalah ilmu ( teori) tentang lambing dan tanda ( dalam bahasa, lalu lintas, kode morse, dan sebagainya). ${ }^{5}$

\footnotetext{
${ }^{3}$ Henry subiakto, Rhamah Ida, Komunikasi Politik, media dan Demokrasi,edisi kedua (Cet. II; Jakarta: Prenadamedia Group, 2012), h. 110.

${ }^{4}$ Hafied Cangara, Komunikasi Politik, Konsep, Teori dan Strategi, Edisi Revisi (Cet. IV; Jakarta: PT Raja Grafindo Persada, 2014), h. 308.

${ }^{5}$ https://kbbi.web.id/semiotika.html.
} 
Semiotika adalah suatu ilmu atau metode analisis untuk mengkaji tanda. Tanda-tanda adalah perangkat yang kita pakai dalam upaya berusaha mencari jalan di dunia ini, ditengah-tengah manusia dan bersama-sama manusia. ${ }^{6}$

Teori Barthes menjelaskan dua tingkat pertandaan yaitu denotasi dan konotasi. Denotasi adalah hubungan eksplisit antara tanda dengan referensi atau realitas dalam pertandaan, sedangkan konotasi adalah aspek makna yang berkaitan dengan perasaan dan emosi serta nilai-nilai kebudayaan dan ideology. ${ }^{7}$

Barthes menjelaskan bahwa sign tidak berdiri sendiri sebagai suatu tanda atau hal yang memiliki arti dibaliknya, namun sign merupakan kombinasi dari signifier dan signifier. Signifier adalah suatu hal, benda, bentuk, visual, atau apapun yang kita lihat dan terima melaui panca indera. Sedangkan signifier adalah makna yang kita terapkan, artikan, dan asosiasikan dengan hal (signifier) yang kita terima. Misalnya, ketika kita melihat bendera merah putih dikibarkan setengah tiang, maka kita akan menafsirkan keadaan tersebut bahwa sedang ada tokoh penting yang meninggal.

Bagi Roland Barthes, semiotika bukanlah suatu perkara, ilmu pengetahuan, disiplin ilmu, pembelajaran, pergerakan, atau bahkan teori, tapi merupakan sebuah petualangan. Semiotika memiliki tujuan untuk menerjemahkan dan menginterpretasikan sign baik berupa verbal, yang disebut juga linguistik, dan nonverbal. Barthes sendiri lebih memfokuskan kajian studi dan penelitiannya pada aspek nonverbal seperti cultural meaning dan visual sign.

\section{Syariat Islam}

Syariat menurut Kamus besar Bahasa Indonesia adalah hukum agama yang menetapkan peraturan hidup manusia, hubungan manusia dengan Allah

\footnotetext{
${ }^{6}$ Alex Sobur. Semiotika Komunikasi (Bandung: PT Remaja Rosdakarya. 2016), h. 15-16.

${ }^{7}$ Amir Piliang,Yasraf Amir. Hipersemiotika Tafsir Cultural Studie Atas Matinya Makna.( Yogyakarta : Jalasutra, 2003). h. 16.
} 
Swt., hubungan manusia dengan manusia dan alam sekitar berdasarkan Alquran dan hadis. ${ }^{8}$

Kata syariah sering kali kita dengar dalam kehidupan sehari-hari. Dengan semakin populernya istilah syariah. Pada dasarnya, pengertian syariah merupakan aturan, ketetapan, dan hukum yang sudah diciptakan oleh Allah bagi seluruh makhluk-Nya. Jika kita selidiki asal-usul kata syariah serta proses perubahannya dalam bentuk dan makna, secara etimologi kata syariah berasal dari bahasa Arab yaitu kata syara'a yang artinya jalan. Sehingga jika disimpulkan, kata syariah juga berarti peraturan. Sedangkan secara terminologi atau istilah, syariah merupakan sebuah sistem aturan Tuhan yang mengatur hubungan manusia dengan Tuhannya, hubungan manusia dengan sesama manusia, maupun hubungan manusia dengan seluruh ciptaan Tuhan di alam semesta ini. ${ }^{9}$

Dalam al-Quran, kata syariat baik berbentuk kata kerja (verb), kata benda, ataupun kata sifat terdapat dalam beberapa ayat :

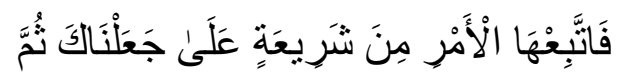

Terjemahnya :

"Kemudian Kami jadikan kamu berada di atas suatu syariat (peraturan) dari urusan (agama itu)..." (QS. Al-Jatsiyah: 18).

$$
\text { وَمِنْهَاجَا شِثِرْ عَةً مِنْكُمْ جَعَلْنَا لِكُلِّ }
$$

Terjemahnya :

"Untuk tiap-tiap umat di antara kamu, Kami berikan aturan dan jalan yang terang." (QS. Al-Maidah: 48)

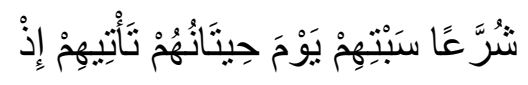

Terjemahnya :

“...ketika mereka melanggar aturan pada hari Sabtu, di waktu datang kepada mereka ikan-ikan (yang berada di sekitar) mereka terapung-apung di permukaan air, dan di hari-hari yang bukan Sabtu..." (QS. Al-A'raf: 163).

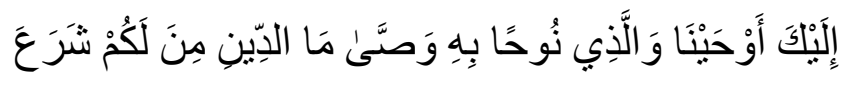

\footnotetext{
${ }^{8}$ https://kbbi.web.id/syariat.html.

${ }^{9}$ https://pengertiandefinisi.com/pengertian-syariah-menurut-para-pakar/
} 
Terjemahnya :

"Dia telah mensyariatkan bagi kamu tentang agama apa yang telah diwasiatkan-Nya kepada Nuh dan apa yang telah Kami wahyukan kepadamu..." (QS. Asy-Syura: 13).

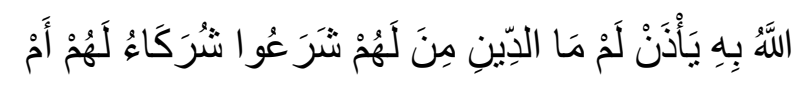

Terjemahnya :

"Apakah mereka mempunyai sembahan-sembahan selain Allah yang mensyariatkan untuk mereka agama yang tidak diizinkan Allah?” (QS. Asy-Syura: 21)

Ibnu Taimiyah mendefinisikan syariat Islam sebagai menaati Allah, menaati Rasul-Nya, dan para pemimpin dari kalangan kita (orang-orang beriman). Pada hakekatnya syariat adalah menaati para rasul dan berada di bawah ketaatan kepada mereka. ${ }^{10}$

Syariat tidak memerintahkan sesuatu halpun selain untuk memberikan manfaat bagi setiap umat manusia. Setiap sendi kehidupan manusia telah lengkap dijabarkan dalam Al-Qur'an dan Hadits, dari hal terbesar sampai hal terkecil. Keluarga, hukum, ekonomi, politik, komunikasi,semuanya lengkap dijelaskan dalam Alquran dan Hadist.

Komunikasi menjadi kemampuan awal yang dimiliki manusia dan langsung disebut Allah untuk diajarkan kepada manusia (QS.Arrahman, 55: 3-4), yakni “ khalaqalinsana, 'allamahulbayaana” (menciptakan manusia, mengajarnya pandai berbicara). Allah pula yang mengajarkan Nabi Adam a.s. ( manusia pertama) kemampuan mengenal nama- nama (simbol- simbol)semua benda di alam raya dan Nabi Adam a.s. juga diminta memberitahukan namanama semua benda tersebut kepada malaikat" (Qs, Al-Baqarah,2:31-33). ${ }^{11}$

Melalui analisis semiotika Rolland Barthes dan Charless sanders Pierce, yang terdiri dari penanda, petanda, makna konotasi, denotasi, maka peneliti akan melihat program Debat Capres dan Cawapres 2019 dalam pandangan Syariat. Islam.

\footnotetext{
${ }^{10}$ (Majmu' Fatawa, Ibnu Taimiyah, 19/309)

${ }^{11}$ Rachmat, Kriyantono. Ilmu Komunikasi. Filsafat dan Etika Ilmunya serta Perspektif Islam (Cet.I; Jakarta: Prenadamedia Group. 2019)h. 342.
} 


\section{METODE PENELITIAN}

Metode penelitian yang digunakan dalam analisis semiotika komunikasi adalah metode penelitian interpretatif. Metode penelitian ini menghendaki pengamatan secara menyeluruh dari semua isi berita (teks), termasuk cara pemberitaan (frame) maupun istilah-istilah yang digunakan. Karena itu dalam penelitian ini analisis terhadap tanda akan dilakukan terhadap semua isi berita, serta istilah-istilah dan cara pemberitaan yang digunakan media yang dijadikan sampel. ${ }^{12}$

Objek penelitian ini adalah debat Capres Cawapres 2019 . Sedangkan unit analisis penelitiannya adalah potongan-potongan gambar atau visual yang diyakini melahirkan perdebatan mengenai sesuai tidaknya nilai- nilai tersebut dengan syariat Islam.

Sumber data terbagi menjadi dua yaitu data primer dan data sekunder. Data Primer adalah data yang diperoleh dari rekaman video original berupa debat Capres Cawapres 2019. kemudian dipilih visual atau gambar dari adegan-adegan debat yang diperlukan untuk penelitian. Data Sekunder adalah data yang diperoleh dari literatur-literatur yang mendukung data primer seperti kamus, internet, bukubuku yang berhubungan dengan penelitian.

Teknik pengumpulan data terdiri dari observasi, wawancara, dan dokumentasi.Setelah data primer dan sekunder terkumpul, kemudian diklarifikasikn sesuai dengan pertanyaan penelitian yang telah ditentukan. Setelah data terklarifikasi, dilakukan analisis data dengan menggunakan teknik analisis semiotika Rolland Barthes dan Charles Sanders Pierce dengan kategori-kategori tanda ikon, indeks dan simbol.

${ }^{12}$ Alex Sobur, Analisis Teks Media Suatu Pengantar Untuk Analisis Wacana, Analisis Semiotik, dan Analisis Framing. (Cet. IV; Jakarta: Kencana , 2006), h. 147-148. 


\section{HASIL PENELITIAN DAN PEMBAHASAN}

Pada pemilu 2019, paslon nomor urut 01 yang terdiri dari pasangan Jokowidodo dan KH.Ma'ruf Amin serta paslon nomor urut 02 yang terdiri dari pasangan Prabowo Subianto dan Sandiaga Salahuddin Uno telah melaksanakan serangkaian debat Capres Cawapres. Acara debat Capres dan Cawapres diadakan sebanyak lima kali. Debat pertama dilaksanankan pada tanggal 17 Januari 2019 bertempat di Hotel Bidakara Jakarta dan dihadiri oleh pasangan Capres dan Cawapres. Debat kedua dilaksanakan pada tanggal 17 Februari 2019 bertempat di Hotel Sultan Jakarta. Debat ketiga dilaksanakan pada tanggal 17 Maret 2019 bertempat di Hotel Sultan Jakarta. Debat keempat dilaksanakan pada tanggal 30 Maret 2019 bertempat di Hotel Shangrila Jakarta. Dan debat terarkhir dilaksanakan pada tanggal 13 April 2019 bertempat di Hotel Sultan Jakarta.

Pada debat pertama yang dilaksanakan pada tanggal 17 Januari 2019 bertempat di Hotel Bidakara Jakarta dihadiri oleh pasangan capres dan cawapres yang ditayangkan di stasiun televisi TVRI, RRI, Kompas TV dan RTV. Dimulai dengan menyanyikan lagu kebangsaan Indonesia Raya, Ketua KPU, Arief Budiman membuka Debat Capres pertama ini. Gemuruh sambutan para pendukung masing-masing, ketika Arief Budiman menyebut nama Joko Widodo Ma'ruf Amien dan Prabowo Subianto - Sandiaga Uno. Adapun tema debat pada putaran pertama adalah Hukum, HAM, Korupsi dan Terorisme. pada debat pertama ini, kedua paslon Capres dan Cawapres diberi kesempatan untuk memaparkan visi dan misi mereka untuk memimpin Indonesia lima tahun kedepan. Paslon nomor urut pertama memberikan nama untuk visi mereka yakni, Indonesia Maju. Mereka berkeyakinan bahwa penegakan hukum dan HAM dapat tercapai untuk lima tahun kedepan. Sedangkan paslon nomor urut dua memaparkan visi Indonesia Menang, dengan alasan bahwa kondisi Indonesia saat ini kurang menguntungkan. Pada saat pemaparan Visi Misi, tampak paslon nomor urut pertama membaca sebah teks, sedangkan paslon nomor urut dua tidak membaca teks.

Pertanyaan pertama dijawab dengan baik oleh paslon nomor urut kedua. Kemudian ditanggapi oleh paslon nomor urut pertama. Tampak senyum simpul 
dari raut wajah paslon nomor urut dua saat jawaban mereka ditanggapi. Dalam segmen kedua debat perdana capres dan cawapres, masing-masing pasangan bergiliran menjawab pertanyaan dengan tema hukum.Pasangan Joko Widodo dan Ma'ruf Amin menjawab pertanyaan soal ketegasan penegakkan hukum dan isu HAM. Dalam penjelasannya, petahana Presiden Joko Widodo menghimbau untuk tidak mempertentangan HAM dan penindakan hukum. Dia mencontohkan, tersangka korupsi ditahan, bukanlah pelanggaran HAM.

Menanggapi penjelasan Jokowi, Prabowo mempertanyakan ketidakadilan yang dilakukan aparat, termasuk soal pernyataan dukungan untuk masing-masing calon. Namun, Jokowi mengatakan bahwa sebagai negara hukum, ada mekanisme yang harus dilakukan sesuai prosedur.

Selain itu Prabowo juga mempermasalahkan penegakkan hukum aparat Jokowi, yang disebutnya berat sebelah. Disebutkan, kepala daerah yang mendukung Jokowi, baik-baik saja, namun di Jawa Timur, yang mendukung Prabowo, ditangkap. Jokowi menjawab: "Jangan menuduh begitu Pak Prabowo. Kalau ada bukti, diajukan saja." Ia menyebut. "Dulu, ada seorang juru kampanye Prabowo, mengaku dipukuli. Pak Prabowo sampai jumpa pers. Ternyata operasi plastik."Yang dimaksud adalah kasus hoaks Ratna Sarumpaet.

Prabowo memberikan pertanyaan kepada Jokowi tentang apakah tidak ada unsur kepentingan dan keberpihakan para pejabat- pejabat yang bekerja pada kabinetnya. Dengan ekspresi wajah yang sedikit melirik kepada Prabowo, Jokowi mengatakan bahwa dirinya tidak memiliki beban- beban masa lalu, sehingga dirinya bebas untuk mengeluarkan peritah- perintah. Dia juga mengatakan bahwa apabila Prabwo memiliki bukti tentang keberpihakan dan ada unsur- unsur kepentingan, silahkan melapor sesuai dengan prosedur hukum yang berlaku.

Pada debat kedua hanya dihadiri oleh Capres nomor urut satu dan dua tanpa didampingi oleh masing- masing cawapres. Dwbat ini dilaksanakan di Hotel Sultan Jakarta. Topik yang dibahas adalah infrastruktur, lingkungan, sumber daya alam, energi, dan pangan. Baik Joko Widodo maupun Prabowo Subianto tidak diberikan kisi-kisi pertanyaan dalam debat kali ini. Prabowo telah menekankan penegakan hukum untuk pelanggaran lingkungan dan menyebutkan adanya kolusi 
pejabat-pengusaha. Direspons oleh Jokowi bahwa pemerintahan saat ini sudah tegas sedemikian sehingga ada vonis sebesar 18T (Rp 18,3 Triliun) kerugian negara. Pada saat Jokowi menyinggung tentang unicorn, Prabowo seolah baru mendengarkan istilah tersebut.

Pada debat ketiga pemilu 2019, hanya dihadiri oleh cawapres dari nomor urut kosong satu dan kosong dua. Beretampat di hotel Sultan Jakarta dipandu oleh Putri Ayuningtiyas dan Alvito Deanova Ginting. Tema debat ketiga ini adalah Pendidikan, Kesehatan, Ketenagakerjaan, Sosial, dan Kebudayaan. Ma'ruf Amin hadir dengan gaya khasnya, mengenakan sarung, jas putih, dan memakai peci. Sedangkan Sandiaga Uno dengan setelan jas lengkap yang semakin menambah kewibawaan. Pada debat ini, Sandiaga menyapa Ma'ruf Amin dengan panggilan “Abah". Dia juga mengucapkan selamat ulang tahun pada Ma'ruf Amin. Debat berlangsung cukup tertib kali ini. Masing- masing kandidat memberikan jawaban dengan gaya khas mereka. Tidak nampak perdebatan yang sengit pada debat ini. Sandiaga Uno terlihat sangat menghormati Ma'ruf Amin dalam setiap sesi. Meskipun ada tanggapan yang diberikan, namun semua yang tampak seperti diskusi antara orang tua dan anak.

Debat keempat diselenggarakan di Hotel Shangri La, Jakarta Pusat dengan media penyelenggara Metro TV, SCTV, dan Indosiar. Debat ini dipandu oleh Retno Pinasti dan Zulfikar Naghi. Debat keempat ini kembali dihadiri oleh calon presiden tanpa diwakili oleh cawapres. berlangsung cukup alot dibanding dengan debat- debat sebelumnya. Pada segmen pertama dengan tema ideologi, diawali dengan pernyataan Prabowo Subianto kepada Jokowi bahwa ada pendukung Jokowi yang menganggap bahwa Prabowo membela Khilafah dan menentang tahlilan. Kemudian ditanggapi dengan santai oleh Jokowi bahwa, dia juga sering dituduh PKI namun tidak dihiraukan. Pada debat ini, juga tampak Prabowo menegur audience yang ribut secara langsung. Prabowo terlihat mencatat semua pertanyaan yang diberikan oleh moderator. Sedangkan Jokowi hanya mendengarkan pertanyaan kemudian langsung menjawab. Pertanyaan bidang pertahanan dan keamanan juga menimbulkan perdebatan. Prabowo yang berlatar belakan TNI terlihat sangat percaya diri dan menguasai tema tersebut. Sedangkan 
Joowi menjawab dan menanggapi berdasarkan pengalamannya sebagai Presiden selama lima tahun terakhir. Meski diwrnai perdebatan pada sesi ini, namun diakhiri dengan rangkulan persahabatan oleh kedua calon presiden.

Debat kelima atau debat terakhir kembali dilaksanakn di Hotel Sultan pada tanggal 13 April 2018, 4 hari sebelum pelaksanaan pemilu serentak dilaksanakan. Tema pada debat kelima ini adalah ekonomi, kesejahteraan sosial, keuangan, investasi, perdagangan serta industri. debat terakhir ini kembali menghadirkan masing- masing paslon kosong satu dan kosong dua.

\section{PEMBAHASAN}

Penelitian semiotika telah banyak dilakukan pada berbagai aspek. Baik dari film,iklan,baliho, pamflet, program televisi, dan sebagainya. Interaksi manusia setiap hari memang tidak pernah lepas dari tanda dan simbol- simbol yang kaya akan makna. Alex Sobur mendefinisikan semiotika sebagai suatu ilmu atau metode analisis untuk mengkaji tanda. Sedangkan menurut Rolland Barthes semiotika megkaji tentang makna tanda, penanda, dan petanda. Menurut Teori Semiotika Charles Sander Peirce, semiotika didasarkan pada logika, karena logika mempelajari bagaimana orang bernalar, sedangkan penalaran menurut Peirce dilakukan melalui tanda-tanda. Tanda-tanda ini menurut Peirce memungkinkan kita berpikir, berhubungan dengan orang lain dan memberi makna pada apa yang ditampilkan oleh alam semesta.

Perdebatan dalam kehidupan manusia adalah hal yang manusiawi terjadi. Sebab tidak mungkin semua manusia memiliki pemikiran yang sama. Tergantung manusia memaknai perdebatan itu sendiri. Seperti halnya dalam menentukan pilihan Presiden. Tidaklah mungkin dua ratus lebih juta jiwa penduduk Indonesia akan memiliki pilihan yang sama. Kegiatan beradu argumen ini sesungguhnya telah tertulis di banyak hadist. Dalam islam debat disebut dengan jidal. Ha ini memang diperbolehkan tetapi hanya jika diperlukan.

Hukum dalam diperbolehkannya debat atau diskusi, Islam telah mengaturnya sedemikian rupa. Allah dan RasulNya menentukan beberapa aturan 
mengenai pembatasan bagaimana suatu perdebatan berlangsung. Ada beberapa tatanan yang harus diperhatikan sebagai seorang mukmin yang baik.

Tatanan yang pertama adalah memperhatikan topik yang diperdebatkan, menguasai apa yang akan diperdebatkan. Sebab berbicara tentang suatu hal yang tak diketahui adalah sia - sia. Tatanan kedua ialah berdebat dengan cara yang baik. Berdebat haruslah berpedoman pada al-qur'an dan hadits yang mana Alqur'an merupakan petunjuk bagi apapun dan siapapun. Ketika berdebat maka sebaiknya fokus pada inti masalah dan menggunakan akal sehat.

Berikutnya, hukum islam tentang perdebatan adalah tidak melakukan debat hanya untuk kesenangan semata. Mereka tidaklah mencari - cari pembenaran dari argumentasinya. Apalagi untuk mendapatkan dukungan dan mencari massa. Tentu ketika melakukan perdebatan, islam melarang untuk menggunakan kata yang keji atau buruk. Selain karena menyakiti orang lain, hal ini bukanlah cerminan dari seorang mukmin yang harusnya lemah lembut ketika berbicara. Debat hanyalah diperlukan untuk meluruskan apa yang batil namun apabila ditolak maka sebaiknya mukmin tersebut menghindari perdebatan.

Dari debat capres diatas, dapat kita lihat bahwa perdebatan yang terjadi masih dalam koridor kewajaran. Meskipun terkadang ada perbedaan pendapat dari masing- masing paslon, namun hal tersbut tidak lantas membuat mereka saling membenci apa lagi sampai memutuskan silaturahmi. Hal- hal yang menjadi topik pembicaraan juga tampak dikuasai dengan baik. Semuanya telah sesuai dengan tatanan berdebat dalam Islam.

\section{PENUTUP}

Perdebatan merupakan hal yang tidak bisa dipisakan dari kehidupan manusia sehari- sehari. Program yang debat yang dilaksanakan oleh KPU dan disiarkan langsung oleh beberapa stasiun TV bertujuan untuk memberikan pandangan, memberikan kesempatan kepada masyarakat Indonesia untuk mengenal calon Presiden Indonesia untuk lima tahun kedepan. Debat tersebut bukanlah untuk memecah belah persatuan masyarakat Indonesia. Deat dalam 
Islam sendiri masih diperbolehkan, selama sesuai dengan komponen- komponen yang tertuang dalam Al-Qur'an dan Hadist Rasulullah.

\section{DAFTAR PUSTAKA}

Brannen, Julia. (2002). Memadu Metode Penelitian: Kualitatif \& Kuantitatif. Cet III; Yogyakarta : Pustaka Pelajar Offset.

Cangara, Hafied. (2014). Pengantar Ilmu Komunikasi. Cet. XIV; Jakarta : Rajawali Pers.

. (2014). Komunikasi Politik, konsep, teori dan strategi edisi Revisi .Cet. IV; Jakarta: PT Raja Grafindo Persada.

Kriyantono, Rachmat. (2019). Ilmu Komunikasi. Filsafat dan Etika Ilmunya serta Perspektif Islam. Cet.Pertama. Jakarta: Prenadamedia Group.

Masyuri dan M. Zainuddin. (2011). Metodologi Penelitian : Pendekatan Praktis dan Aplikatif. Cet. III; Bandung : PT Rafika Aditama.

Nimmo, Dan. (2004). Komunikasi Politik.Komunikator, Pesan dan Media. Cet.V; Bandung: PT.Remaja Rosda Karya.

Nimmo, Dan. (2006). Komunikasi Politik.Khalayak dan Efek. Cet.IV; Bandung: PT.Remaja Rosda Karya.

Piliang,Yasraf Amir. (2003). Hipersemiotika Tafsir Cultural Studie Atas Matinya Makna..Yogyakarta : Jalasutra.

Sobur, Alex. (2006). Analisis Teks Media Suatu Pengantar Untuk Analisis Wacana, Analisis Semiotik, dan Analisis Framing. Cet. IV; Jakarta: Kencana.

Subiakto,Henry dan Rhamah Ida. (2012). Komunikasi Politik, media dan Demokrasi, Edisi kedua. Cet. II; Jakarta: Prenadamedia Group.

Suwartono. (2014). Dasar-Dasar Metodologi Penelitian. Cet. I; Yogyakarta : Andi.

\section{Referensi Lain}

https://id.wikipedia.org/wiki/Pemilihan_umum_di_Indonesia

https://kbbi.web.id/syariat.html.

https://pengertiandefinisi.com/pengertian-syariah-menurut-para-pakar/ 